Cell Research (2001); 11(3):237-243

http://www.cell-research.com

\title{
Agrobacterium-mediated transformation and assessment of factors influencing transgene expression in loblolly pine (Pinus taeda L.)
}

\author{
TANG WEI* \\ North Carolina State University, 2900 Ligon St., Raleigh, NC 27607, USA
}

\begin{abstract}
This investigation reports a protocol for transfer and expression of foreign chimeric genes in loblolly pine (Pinus taeda L.). Transformation was achieved by co-cultivation of mature zygotic embryos with Agrobacterium tumefaciens strain LBA4404 which harbored a binary vector (pBI121) including genes for b-glucuronidase (GUS) and neomycin phosphotransferase (NPTII). Factors influencing transgene expression including seed sources of loblolly pine, concentration of bacteria, and the wounding procedures of target explants were investigated. The expression of foreign gene was confirmed by the ability of mature zygotic embryos to produce calli in the presence of kanamycin, by histochemical assays of GUS activity, by PCR analysis, and by Southern blot. The successful expression of the GUS gene in different families of loblolly pine suggests that this transformation system is probably useful for the production of the genetically modified conifers.
\end{abstract}

Key words: Pinus taeda L., Agrobacterium tumefaciens, gene transfer, gene expression.

\section{INTRODUCTION}

Recombinant DNA technology is a powerful tool for the introduction of foreign genes into long-lived perennials and for fundamental studies of gene expression. Using such techniques, we can overcome the difficulties associated with the breeding of a longlived perennial. At present, although considerable research effort has been devoted to the genetic engineering of forest trees, it has lagged behind advances made in herbaceous crops due both to economics and the recalcitrant nature of woody perennials to in vitro manipulation[1], [2]. Transient expression was observed in electroporated protoplasts of loblolly pine (Pinus taeda L.)[3], as well as black spruce (Picea mariana)[4] tissues transformed by particle bombardment. Transgenic plantlets have been achieved in Norway spruce (Picea abies)[5], white spruce (Picea glauca)[6], black spruce (Picea mariana)[1], and radiata pine (Pinus radiata)[7] via microprojectile bombardment.

\footnotetext{
* Corresponding author: Tel: (919)-515-7800; Fax: (919)-5157801; E-mail: wtang@unity.ncsu.edu

Received May-8-2001 Revised July-25-2001 Accepted July-262001
}

Agrobacterium-mediated transformation has been the favored method for introduction of foreign genes into plants. Compared to the particle bombardment protocol, Agrobacterium is a much more efficient transformation tool in compatible plant species. Thus far, the numerous efforts to apply the techniques of Agrobacterium-mediated transformation to coniferous species have had limited success. However, successful transfer of foreign genes into conifers by Agrobacterium and the regeneration of transgenic plants have been achieved with larch (Larix deciduas)[8], hybrid larch (L. KaempfericL. Decidua)[9], Norway spruce (Picea abies)[10], and white pine (Pinus strobes)[2].

This study investigated transformation of loblolly pine mature zygotic embryos using the gene transfer system mediated by Agrobacterium tumefaciens. Factors including seed sources, concentration of bacteria, and wounding procedures that influence transgene expression are evaluated. Loblolly pine is an economically important forest tree that is widely planted in tropical and subtropical regions. Studies on gene transfer by Agrobacterium tumefaciens[11], transient expression of a luciferase gene[3], and tran- 
sient expression from microprojectile-mediated DNA transfer[12] had been reported in loblolly pine. Yet there is no report on the systemic analysis and application of factors influencing transgene expression, such as seed source, concentration of bacteria, and wounding method. In this study, we report the Agrobacterium tumefaciens-mediated stable transformation and the improved regeneration of transgenic plants in loblolly pine.

\section{MATERIALS AND METHODS}

\section{Plant materials and Agrobacterium strain}

Mature seeds of five different seed sources of loblolly pine were collected from Yingde Seed Orchard (E-22, E-311, and E-440), Guangdong Province, China, and South Amercia (J-56, S-1003) in October 1996, and stored at $4^{\circ} \mathrm{C}$ until use. Mature zygotic embryos were isolated from megagametophytes after the seeds were surface-sterilized in $0.1 \%$ mercuric chloride for $8-10 \mathrm{~min}$ followed by five successive rinses in sterile distilled water. The embryos were cultured on TE medium containing $2 \mathrm{mg} / \mathrm{l} \alpha$ naphthaleneacetic acid (NAA) and $0.5 \mathrm{mg} / \mathrm{l}$ indole-3-butyric acid (IBA) for 3-5 d before mature zygotic embryos were used for transformation experiments. Agrobacterium tumefaciens strain LBA4404 containing the binary plasmid pBI121 (Clontech, Palo Alto, CA) was used in the transformation experiments. The plasmid pBI121 carries the neomycin phosphotransferase (NPTII) gene and $\beta$-glucuronidase (GUS) gene. The neomycin phosphotransferase (NPTII) gene is under the control of the nopaline synthase (nos) promoter and the terminator from nopaline synthase (nos) which provides polyadenylation signal. The neomycin phosphotransferase (NPTII) gene confers kanamycin resistance. The $\beta$-glucuronidase (GUS) activity is under the control of the cauliflower mosaic virus $35 \mathrm{~S}$ promoter and the terminator from nopaline synthase (nos) provides polyadenylation. Agrobacterium tumefaciens was grown overnight at $28^{\circ} \mathrm{C}$ in liquid YEP medium[13] supplemented with 25 $\mathrm{mg} / \mathrm{l} \mathrm{rifampicin,} 50 \mathrm{mg} / \mathrm{l}$ streptomycin, and $50 \mathrm{mg} / \mathrm{l} \mathrm{kanamycin}$. The overnight culture was diluted with liquid TE medium to $4 \times$ 108 cells/ml for transformation of mature zygotic embryos. Influence of different concentrations of bacteria $(0.5,1,2,4,8,16$, and $32 \times 10^{8}$ cells $/ \mathrm{ml}$ ) on GUS expression was investigated by using mature zygotic embryos of seed sources J-56, S-1003, and E-22 as target explants.

\section{Co-cultivation and selection}

Embryos were immersed in diluted bacterial suspension for 15-25 min, and co-cultivated at $25^{\circ} \mathrm{C}$ for 3-5 d in the dark on TE medium supplemented with $2 \mathrm{mg} / \mathrm{l} \mathrm{NAA}$ and $0.5 \mathrm{mg} / \mathrm{l} 6$ benzyladenine (BA). During co-cultivation, different concentration of kanamycin, coniferyl alcohol, and antibiotics were tested for improving transformation frequency. Co-cultivated mature zygotic embryos were then washed 4-5 times in sterile distilled water for decreasing the concentration of Agrobacterium tumefaciens. After embryos were washed by a cefotaxime (250 $\mathrm{mg} / \mathrm{l}$ ) solution for $20 \mathrm{~min}$, they were extensively washed again in sterile distilled water. Zygotic embryos were placed on sterile filter paper to remove excess liquid and transferred onto callus induction medium supplemented with $500 \mathrm{mg} / \mathrm{l}$ carbenicillin and $15 \mathrm{mg} / \mathrm{l}$ kanamycin. Callus induction medium consists of TE medium containing $4 \mathrm{mg} / \mathrm{l} \mathrm{NAA}, 2 \mathrm{mg} / \mathrm{l} \mathrm{BA}$, and $0.5 \mathrm{mg} / \mathrm{l} \mathrm{IBA}$. After three weeks, mature zygotic embryos were transferred to fresh callus induction medium and kept under selective pressure until kanamycin resistant callus and adventitious bud regenerated. The effect of wounding methods on the efficiency of uidA gene transfer was tested 3 weeks after inoculation. Scraped mature zygotic embryos, as well as particle bombardment wounded and ultrasound wounded embryos were tested. These wounding methods were performed following the protocols published by Humara et al[14] and Trick and Finer[15] and by using seed source E-22 as target explants.

\section{Plantlet regeneration and acclimatization}

Plantlet regeneration of transformed tissues was conducted as previously described by Tang et al[16]. Differentiation medium was TE medium[16] containing $2 \mathrm{mg} / \mathrm{l} \mathrm{BA,} \mathrm{0.5mg/l} \mathrm{IBA,}$ $500 \mathrm{mg} / \mathrm{l}$ casein hydrolysate, $500 \mathrm{mg} / \mathrm{l}$ glutamine, $500 \mathrm{mg} / \mathrm{l}$ carbenicillin, and $15 \mathrm{mg} / \mathrm{l}$ kanamycin. All media were supplemented with $3 \%$ sucrose and $0.7 \%$ agar. The $\mathrm{pH}$ was adjusted to 5.8 prior to autoclaving for $30 \mathrm{~min}$ at $115^{\circ} \mathrm{C}$. Differentiation of transformed tissue was conducted at $25^{\circ} \mathrm{C}$ under a $16 \mathrm{~h}$ photoperiod. Both rooting of regenerated shoots and acclimatization of whole regenerated plantlets were conducted in the greenhouse according to a procedure previously described[16].

\section{Histochemical assays of GUS activity}

Histochemical analysis of GUS expression was performed 3$5 \mathrm{~d}$ after co-cultivation with Agrobacterium tumefaciens. Tissues were incubated in staining buffer containing $100 \mathrm{mM}$ sodium phosphate, $50 \mathrm{mM}$ 5-bromo-4-chloro-3-indolyl- $\beta$-D-glucuronic acid cyclohexylammonium salt, $0.1 \%$ b-mercaptoethanol, and $0.1 \%$ Triton $\mathrm{X}-100(\mathrm{pH} 7.2)$ at $37^{\circ} \mathrm{C}$ for $16 \mathrm{~h}$. After embryos were bleached with $70 \%$ ethanol for at least $24 \mathrm{~h}$, embryos expressed GUS were counted [17]. A sample was scored as GUS positive if there was at least one discrete dark-blue region on the tissue.

\section{PCR analysis and Southern blot}

Loblolly pine genomic DNA was prepared by the method of W agner et al[18]. The primers for amplification from total DNA w ere nos 3' primer 3' -GTTGCCGGTCTTGCGATG-5' and 3' -TAGCGAAGACGGCAA-5', and 35S promoter primer 3' -CTGACGTAAGGGATGACGC-5' and 3' -CAGATCCTTTG CAGA-5' . A total of 100-300ng genomic DNA was amplified in a $50 \mu \mathrm{l}$ reaction mix containing $200 \mu \mathrm{M}$ each of dATP, dCTP, d GTP, dTTP, $0.25 \mu \mathrm{M}$ of each primer, $2 \mathrm{U}$ Taq DNA polymerase (Promega) $1.5 \mathrm{mM} \mathrm{MgCl}_{2}$, and $5 \mu \mathrm{l} 10 \times$ Taq DNA polymerase buffer. The reaction was incubated in a programmable Amplitr on I Thermal Cycler for 30 cycles (denaturation at $9^{\circ} \mathrm{C}$ for $40 \mathrm{~s}$, annealing at $50^{\circ} \mathrm{C}$ for $1 \mathrm{~min}$, and extension at $72^{\circ} \mathrm{C}$ for $1.5 \mathrm{~min}$ ). The amplified bands were observed under UV after electrophore sis on a $0.8 \%$ agarose gel. For Southern blot, $30 \mu \mathrm{g}$ DNA was di 
gested overnight with restriction enzyme EcoRI (Boehringer Ma nnheim) at $37^{\circ} \mathrm{C}$. Fragments were separated by electrophoresis o $\mathrm{n}$ a $0.8 \%$ agarose gel in TAE and denatured with $0.5 \mathrm{~N} \mathrm{NaOH}, \mathrm{t}$ hen transferred to a nylon membrane using alkali transfer buf fer. The DNA fixed on membranes was hybridized with the uidA probe, which was labeled with ${ }^{32} \mathrm{P}\left(\left[\alpha-{ }^{32} \mathrm{P}\right]-\mathrm{dCTP} 110 \mathrm{TBp} / \mathrm{mmo}\right.$ l; Amersham, Buckinghamshire, England) (Ready to Go Syste $\mathrm{m})$, according to standard protocols[13]. Membranes were wash ed twice in $2 \times \mathrm{SSC}, 0.1 \% \mathrm{SDS}$ at $65^{\circ} \mathrm{C}$ for $5 \mathrm{~min}$ each, once in 0 . $5 \times \mathrm{SSC}, 0.1 \% \mathrm{SDS}$ at $62^{\circ} \mathrm{C}$ for $15 \mathrm{~min}$, and once in $0.1 \times \mathrm{SSC}, 0$. $1 \%$ SDS at room temperature for $30 \mathrm{~min}$, and exposed to Kodak $\mathrm{X}-\mathrm{Omat}-\mathrm{AR}$ films at $80^{\circ} \mathrm{C}$ for three days.

\section{RESULTS}

\section{Transformation of mature zygotic embryos}

Before the transformation experiments, influence of different concentration of kanamycin $(0$, $5,10,15,20,25$, and $30 \mathrm{mg} / \mathrm{l})$ on growth of mature zygotic embryos and callus was tested to identify the optimal concentration for selecting transformed mature zygotic embryos. Callus and adventitious bud formation were completely inhibited at $15 \mathrm{mg} /$ 1 kanamycin in the 4 th week of culture. Embryos also were cultured on callus induction medium containing $500 \mathrm{mg} / \mathrm{l}$ carbenicillin or claforan to identify an appropriate antibiotic to remove bacteria without inhibiting callus and adventitious buds formation. Of the antibiotics, carbenicillin did not inhibit callus and adventitious bud formation at 500 $\mathrm{mg} / \mathrm{l}$ concentration, but claforan did. Therefore, $15 \mathrm{mg} / \mathrm{l} \mathrm{kanamycin}$ and $500 \mathrm{mg} / \mathrm{l}$ carbenicillin were used for selection. Callus was formed on cotyledons, hypocotyl, and radicles of embryos, two to three weeks after inoculation with bacteria. The frequency of kanamycin-resistant callus formation of 5 seed sources of loblolly pine was $9.7 \%-16.1 \%$ in the 8 th $\mathrm{w}$ after inoculation (Tab 1). To improve the transformation efficiency, different concentrations of coniferyl alcohol were added to media during the period of co-cultivation. Eight weeks after inoculation, the frequency of kanamycin-resistant callus formation was obviously increased. The optimal concentration of coniferyl alcohol for improving the transformation efficiency was $100 \mu \mathrm{M}$.

\section{Plantlet regeneration and acclimatization}

After subculture on fresh callus induction medium containing NAA, BA, and IBA for six weeks, kanamycin-resistant calli (Fig 1d) weretransferred to dif- ferentiation medium to induce adventitious buds. After 16-18 weeks, adventitious buds were formed on the surface of kanamycin resistant calli (Fig 1e). The frequency of adventitious bud formation was 11 . $2 \%-25.4 \%$ on the differentiation medium supplemented with BA and IBA in the 8th w of culture (Tab 2 ). Both rooting of adventitious buds and acclimatization of regenerated plantlets were carried out according to a procedure previously described16]. Rooting frequency of 7.3\%-18.9\% was observed and the phenotype of regenerated plantlets appeared similar to the untreated control. Twenty-six regenerated plantlets from five seed sources of loblolly pine were transferred from culture flasks into a perlite:peatmoss: vermiculite $(1: 1: 1 \mathrm{v} / \mathrm{v} / \mathrm{v})$ soil mixture, and twelve acclimatized plantlets were successfully established in the field (Fig 1f).

Tab 1. Influence of different seed sources of loblolly pine on the induction frequency (\%) of kanamycin-resistant calli. Each treatment was replicated three times, and each replicate consisted of 200-250 mature zygotic embryos. Values represent the mean \pm S.E. In each column, values with different letters are significantly different $(\mathrm{P} \leqslant 0.05)$.

\begin{tabular}{lcccc}
\hline Geno- & \multicolumn{4}{c}{ Culture Time (Weeks) } \\
\cline { 2 - 5 } types & 5 & 6 & 7 & 8 \\
\hline J-56 & $6.1 \pm 1.0 \mathrm{a}$ & $8.2 \pm 1.2 \mathrm{a}$ & $11.2 \pm 1.0 \mathrm{a}$ & $14.1 \pm 1.1 \mathrm{a}$ \\
S-1003 & $6.6 \pm 0.8 \mathrm{a}$ & $8.1 \pm 1.0 \mathrm{a}$ & $13.3 \pm 1.1 \mathrm{a}$ & $16.1 \pm 1.2 \mathrm{a}$ \\
E-22 & $4.5 \pm 0.5 \mathrm{~b}$ & $6.2 \pm 1.0 \mathrm{~b}$ & $9.8 \pm 1.1 \mathrm{~b}$ & $11.7 \pm 1.1 \mathrm{~b}$ \\
E-311 & $4.6 \pm 0.5 \mathrm{~b}$ & $5.8 \pm 0.8 \mathrm{~b}$ & $8.3 \pm 0.5 \mathrm{~b}$ & $9.9 \pm 1.0 \mathrm{~b}$ \\
E-440 & $3.2 \pm 0.8 \mathrm{~b}$ & $5.5 \pm 0.5 \mathrm{~b}$ & $7.6 \pm 0.8 \mathrm{~b}$ & $9.7 \pm 0.8 \mathrm{~b}$ \\
\hline
\end{tabular}

Tab 2. Influence of different seed sources of loblolly pine on the regeneration frequency (\%) of transgenic adventitious buds. Each treatment was replicated four times, and each replicate consisted of 90-150 callus tissues. Values represent the mean \pm S.E. In each column, values with different letters are significantly different $(\mathrm{P} \leqslant 0.05)$.

\begin{tabular}{lcccc}
\hline Geno- & \multicolumn{4}{c}{ Culture Time (Weeks) } \\
\cline { 2 - 5 } types & 5 & 6 & 7 & 8 \\
\hline J-56 & $18.1 \pm 1.0 \mathrm{a}$ & $20.2 \pm 1.2 \mathrm{a}$ & $21.2 \pm 1.0 \mathrm{a}$ & $23.1 \pm 1.1 \mathrm{a}$ \\
S-1003 & $19.6 \pm 1.8 \mathrm{a}$ & $21.1 \pm 1.0 \mathrm{a}$ & $22.3 \pm 1.1 \mathrm{a}$ & $25.4 \pm 1.2 \mathrm{a}$ \\
E-22 & $17.5 \pm 1.5 \mathrm{a}$ & $18.2 \pm 1.7 \mathrm{a}$ & $20.8 \pm 1.1 \mathrm{a}$ & $22.1 \pm 1.1 \mathrm{a}$ \\
E-311 & $7.6 \pm 0.5 \mathrm{~b}$ & $9.8 \pm 0.8 \mathrm{~b}$ & $10.3 \pm 1.5 \mathrm{~b}$ & $12.9 \pm 1.0 \mathrm{~b}$ \\
E-440 & $6.2 \pm 0.8 \mathrm{~b}$ & $8.5 \pm 0.5 \mathrm{~b}$ & $9.6 \pm 0.8 \mathrm{~b}$ & $11.2 \pm 0.8 \mathrm{~b}$ \\
\hline
\end{tabular}



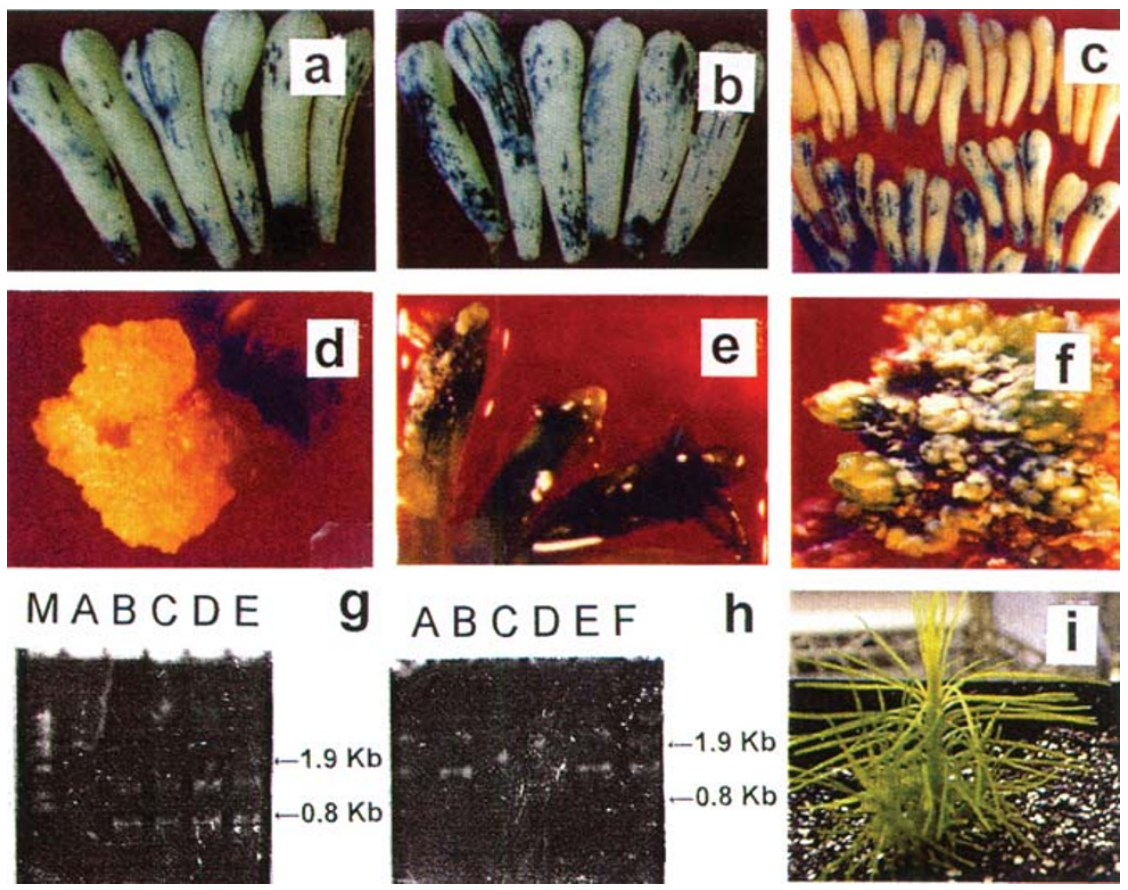

Fig 1. Agrobacterium tumefaciens-mediated transformation and transgenic plant regeneration in loblolly pine. (a-c) GUS expressing on hypocotyl (bar $=0.5 \mathrm{~cm}$ ). (b) GUS expressing on callus derived from cotyledons, and on hypocotyl and radicle (bar $=0.5 \mathrm{~cm}$ ). (c) GUS expressing on callus derived from hypocotyl $(\mathrm{bar}=0.7 \mathrm{~cm})$. (d) Kanamycin- resistant calli derived from cotyledons $(\mathrm{bar}=0.5 \mathrm{~cm})$. (e) Kanamycin-resistant adventitious shoots $(\mathrm{bar}=0.5 \mathrm{~cm}$ ). (f) Transgenic regenerated plantlet established in soil ( $\mathrm{bar}=1 \mathrm{~cm}$ ). (g) PCR analysis of DNA from transgenic calli (lane M molecular markers, lanes A through E J-56, S-1003, E-22, E-311, and E-440). (h) PCR analysis of DNA from transgenic regenerated plantlets (lane A S-1003, lane B pBI121, lane C control S-1003, lanes D through F E-22, E-311, and E-440).

Tab 3. Influence of different wounding procedures on gene transfer into loblolly pine mature zygotic embryos (E-22)

\begin{tabular}{lccc}
\hline $\begin{array}{l}\text { Wounding } \\
\text { methods }\end{array}$ & $\begin{array}{c}\text { Number of } \\
\text { assayed } \\
\text { embryos }\end{array}$ & $\begin{array}{c}\text { Percentage of } \\
\text { GUS-positive } \\
\text { embryos }\end{array}$ & $\begin{array}{l}\text { Mean of GUS } \\
\text { spots/embryo }\end{array}$ \\
\hline None & 375 & $15.1 \mathrm{a}$ & $6.2 \pm 0.8 \mathrm{a}$ \\
Scrape & $32117.3 \mathrm{a}$ & $9.7 \pm 1.0 \mathrm{a}$ & \\
Bombardment & 319 & $29.8 \mathrm{~b}$ & $23.1 \pm 2.0 \mathrm{~b}$ \\
Ultrasound & 312 & $32.7 \mathrm{~b}$ & $34.7 \pm 2.3 \mathrm{~b}$ \\
Control & 151 & $0 \mathrm{c}$ & $0 \mathrm{c}$ \\
\hline
\end{tabular}

Data are presented as the mean \pm S.E. number of at least four different experiments. Values with different letters are significantly different $(P \leqslant 0.05)$

\section{Histochemical assays of GUS activity}

After inoculation for 5-10 d, histochemical GUS assay of mature zygotic embryos was carried out. Accumulation of GUS enzyme was not detected in un-inoculated control embryos. Mature zygotic embryos of all five seed sources of loblolly pine inoculated with Agrobacterium tumefaciens expressed GUS activity on hypocotyl, cotyledons, and radicle (Fig 1 a-c), respectively. Results on testing different concentration of bacteria showed that the highest frequency (\%) (embryos expressed GUS/embryos tested) of uidA gene expression embryos was obtained when the concentration of bacteria was $4 \times$ $10^{8}$ cells/ml (Fig 2 ). The frequency of embryos expressing GUS activity ranged from $8.7 \%$ to $16.9 \%$ (Fig 3) among different seed sources at this concentration. Among different wounding procedures, the highest frequency of uidA gene expression embryos was obtained after embryos were wounded by ultrasound (Tab 3). To confirm that the positive X-Gluc in mature zygotic embryos was not due to the presence of viable Agrobacterium tumefaciens in the explants, both GUS+ and GUScallus was homogenized and plated on YEP medium. As expected after 1 week of inoculation at $28^{\circ} \mathrm{C}$, no 
colonies were visible from any of the putatively transformed mature zygotic embryos.

\section{PCR analysis of the transformants}

PCR analysis was carried out as a rapid identification for the presence of the GUS gene in kanamycin resistant calli from five seed sources of loblolly pine. The expected $1.9 \mathrm{~kb}$ band and $0.8 \mathrm{~kb}$ band were amplified in the kanamycin resistant and GUS expressed calli (Fig 1g). No GUS band was amplified in the non-transformed calli. Some of the regenerated plantlets derived from kanamycin- resistant calli of five seed sources of loblolly pine were also checked by PCR (Fig 1h). All of the kanamycin-resistant plantlets tested showed the $1.9 \mathrm{~kb}$ band and $0.8 \mathrm{~kb}$ band. Thus, these regenerated plantlets from were confirmed to be transformants.

\section{Southern blot of transgenic plants}

Trangenic plantlets from independent transformation events were analyzed by Southern hybridization (Fig 4). No hybridization signals were detected in non- transformed control plants whereas signals were observed in transgenic plants. This confirms the presence of foreign genes integrated into the Pinus taeda genome. The Southern results of regenerated transformed plants showed one band that represented junctions between T-DNA and adjacent plant DNA. These findings show that these are transformants in which the GUS gene has integrated at one site in the plant genome. However, the integration of tandem or multimer copies in regenerated transformed plants was observed in Pinus radiata via particle bombardment[7].

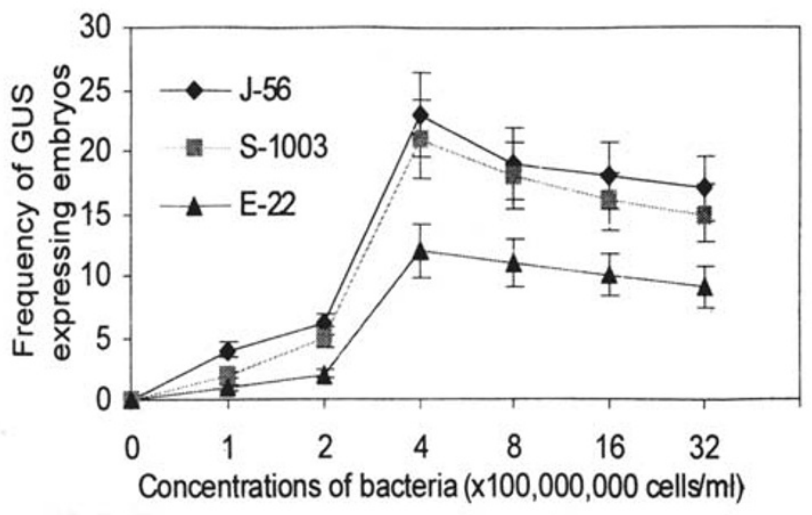

Fig 2. Influence of different concentrations of bacteria on GUS expression in loblolly pine.

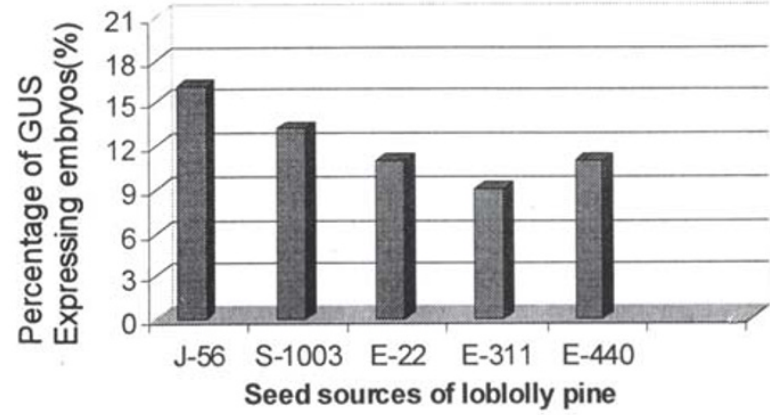

Fig 3. Influence of different seed sources of loblolly pine on GUS expressing. Each treatment consisted of 160 transformed mature zygotic embryos.

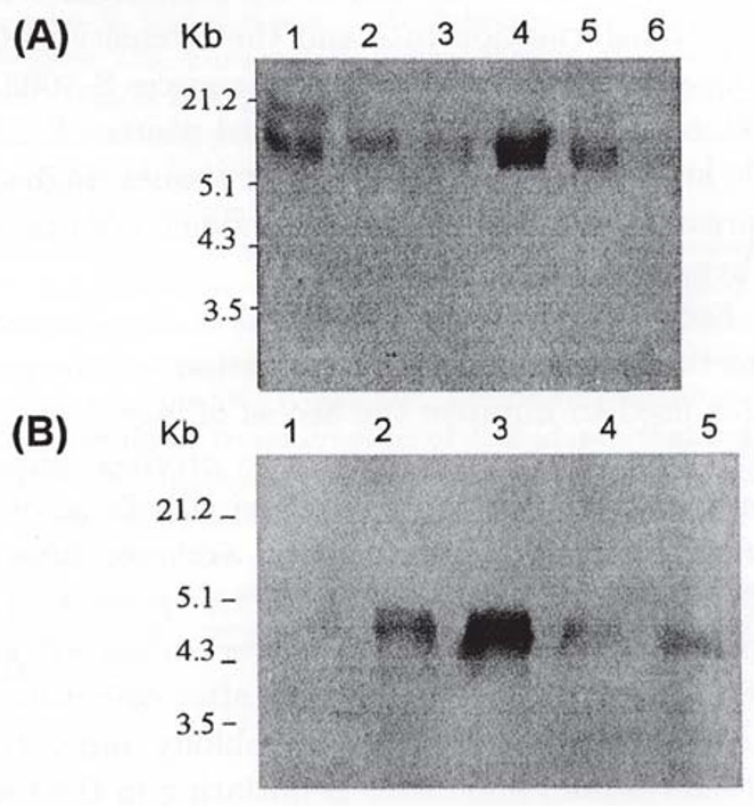

Fig 4. Southern blot analysis of transgenic plants of loblolly pine. (A) Genomic DNA was digested with the restriction enzyme EcoRI and hybridized with the GUS probe labeled BamHI and SacI fragment of pBI121). Lane P pBI121 plasmid control (5 pg), lane 1-4 DNA from transgenic plants derived from family J-56, S-1003, E-311, and E-440, respectively (30 $\mu \mathrm{g}$ ), Lane C DNA from non-transformed plant control (30 $\mu \mathrm{g})$. Molecular weight marker in $\mathrm{kb}$ was indicated on left. (B) Genomic DNA was digested with the restriction enzyme EcoRI and HindIII and hybridized with the GUS probe ([ $\left.\alpha{ }_{-}^{32} \mathrm{P}\right]$-dCTP) labeled BamHI and SacI fragment of pBI121). Lane C DNA from non-transformed plant control (30 mg), lane 1-3 DNA from transgenic plants derived from family E-22, E-311, and E-440, respectively (30 $\mu \mathrm{g})$, lane P pBI121 plasmid control (5 pg).

\section{DISCUSSION}

Effects on the efficiency of foreign gene transfer by various factors were evaluated using 
Agrobacterium tumefaciens LBA 4404. These factors included five seed sources, different concentration of bacteria, and different wounding procedures. The data on Agrobacterium tumefaciens-mediated transformation of five seed sources of loblolly pine presented here provide a reliable procedure for the regeneration of transgenic loblolly pine plantlets. This is the first report on transgenic plantlet regeneration through Agrobacterium tumefaciens-mediated transformation in five seed sources (J-56, S1003, E-22, E-311, and E-440) of loblolly pine. In the present investigation, we found that the efficiency of the transformation events was dependent on the organs and tissues infected as well as the seed sources used. High transformation rate and the intensity of GUS expression were observed in seed sources S-1003 and J-56, and to a lesser extent in seed sources E-22, E-311, and E-440. Among different tissues, high GUS expression was observed in cotyledons, not observed in hypocotyls and radicles.

Factors that can be optimized in Agrobacterium tumefaciens-mediated transformation are the procedures used to improve the access of Agrobacterium and also to induce plant cells to produce phenolic compounds for vir gene expression. In addition, the selection of mature zygotic embryos after co-cultivation was also critical for the success of the experiment. The best results were observed when selection was applied four weeks after co-cultivation in all of five seed sources of loblolly pine, tissue growth resumes and callus is initiating in the fourth week. The addition of $100 \mu \mathrm{M}$ coniferyl alcohol during the cocultivation step increased the induction frequency of kanamycin resistant calli. Similar results have been reported by Levee et al[9]. Coniferyl alcohol is a phenolic compound that is released by the wounded plant cells and is a virulence inducer similar to acetosyringone[19] and syringaldehyde. It plays an important role in the natural infection of plants by Agrobacterium tumefaciens because it activates the virulence genes of the Ti pasmid that initiates the transfer of the T-DNA region into a plant. A positive effect of phenolic compounds on Agrobacterium tumefaciens-mediated transformation has been demonstrated in many plant species, such as Arabidopsis thaliana[20]. Our results indicate that the improvement of coniferyl alcohol on the Agrobacterium tumefaciens-mediated transformation of mature zygotic embryos vary among seed sources.

Other parameters possibly improving transformation frequency are bacterial density, co-cultivation time, and wounding procedures. The highest GUS expression frequency was obtained when concentration of bacteria was $4 \times 10^{8}$ cells $/ \mathrm{ml}$ in this study. Increasing co-cultivation time improving transient GUS expression was also observed. These are in agreement with Humara et al[14]. Ultrasonication has been reported to mediate gene transfer in plant suspension cells and intact pieces of tissues[14]. Our results demonstrate the advantages of combined sonication of loblolly pine embryos and Agrobacterium tumefaciens to achieve high levels of further expression of the uidA gene, similar to the reports by Trick and Finer[15]. Stable transformation was further confirmed by PCR and Southern blot analysis on putative transgenic tissues and plants. The present system for the transformation will allow the selective improvement of single traits by the introduction of economically important genes into loblolly pine.

\section{ACKNOWLEDGEMENTS}

I wish to thank Professor Y.C. Tian and F. Ouyang for encouragement, Professor T. M. Hinckley for suggestion and Professor R. Sederoff for comments on this manuscript.

\section{REFERENCES}

[1] Charest PJ, Devantier Y, Lachance D. Stable genetic transformation of Picea mariana (black spruce) via microprojectile bombardment. in vitro Cellular and Developmental Biology 1996; 32:91-9.

[2] Levee V, Garin E, Klimaszewska K, Sequin A. Stable genetic transformation of white pine (Pinus strobes L.) after co-cultivation of embryogenic tissues with Agrobacterium tumefaciens. Molecular Breeding 1999; 5: 429-40.

[3] Gupta PK, Dandekar AM, Durzan DJ. Somatic proembryo formation and transient expression of a luciferase gene in Douglas fir and loblolly pine protoplasts. Plant Science 1988; 58:85-92.

[4] Duchesne LC, Charest PJ. Transient expression of the bglucuronidase gene in embryogenic callus of Picea mariana following microprojection. Plant Cell Reports 1991; 10: 191-4.

[5] Walter C, Grace LJ, Donaldson SS, Moody J, Gemmell JE, van der Maos S, Kvaalen H, Lonneborg A. An efficient Biolistic transformation protocol for Picea abies embryogenic tissue and regeneration of transgenic plants. Cana- 
dian Journal of Forest Research 1999; 29:1539-46.

[6] Ellis DD, McCabe DE, Mcinnis S, Ramachandran R, Russell DR, Wallace KM, Martinell BJ, Roberts DR, Raffa KF, McCown BH. Stable transformation of Picea glauca by particle acceleration. Biotechnology 1993; 11:84-9.

[7] Walter C, Grace LJ, Wagner A, White DWR, Walden AR, Donaldson SS, Hinton H, Gardner RC, Smith DR. Stable transformation and regeneration of transgenic plants of Pinus radiata D. Don. Plant Cell Reports 1998; 17:460-9.

[8] Huang Y, Diner AM, Karnosky DF. Agrobacterium rhizogenes-mediated genetic transformation and regeneration of a conifer: Larix deciduas. in vitro Cellular Developmental Biology 1991; 27:201-7.

[9] Levee V, Lelu MA, Jouanin L, Cornu D, Pilate G. Agrobacterium tumefaciens-mediated transformation of hybrid larch (Larix kaempferi ? L. deciduas) and transgenic plant regeneration. Plant Cell Reports 1997; 16:680-5.

[10] Wenck AR, Quinn M, Whetten RW, Pullman G, Sederoff R. High-efficiency Agrobacterium-mediated transformation of Norway spruce (Picea abies) and loblolly pine (Pinus taeda). Plant Mol Biology 1999; 39:407-16.

[11] Sederoff R, Stomp AM, Chilton WS, Moore LW. Gene transfer into loblolly pine by Agrobacterium tumefaciens. Biotechnology 1986; 4:647-9.

[12] Stomp AM, Weissinger A, Sederoff R.R. Transient expression from microprojectile-mediated DNA transfer in Pinus taeda. Plant Cell Reports 1991; 10:187-90.

[13] Sambrook J, Fritsch EF, Maniatis T. Molecular Cloning: a laboratory manual. 2nd ed., Cold Spring Harbor, NY, 1989.

[14] Humara JM, Lopez M, Ordas RJ. Agrobacterium tumefaciens-mediated transformation of Pinus pinea $\mathrm{L}$.
Cotyledons: an assessment of factors influencing the efficiency of uidA gene transfer. Plant Cell Reports 1999; 19:51-8.

[15] Trick HN, Finer JJ. Sonication-assisted Agrobacteriummediated transformation of soybean [Glycine max] (L.) Merrill] embryogenic suspension culture tissue. Plant Cell Reports 1998; 17:482-8.

[16] Tang W, Ouyang F, Guo ZC. Plant regeneration through organogenesis from callus induced from mature zygotic embryos of loblolly pine. Plant Cell Reports 1998; 17: 557-60.

[17] Jefferson RA, Kavanagh TA, Bevan MW. GUS fusion: bglucuronidase as a sensitive and versatile gene fusion marker in higher plants. EMBO Journal 1987; 6:3901-7.

[18] Wagner DB, Furnier GR, Saghai-Maroof MA, Williams SM, Dancik BW, Allard RW. Chloroplast DNA polymorphisms in lodgepole and jack pine and their hybrids. Proceedings of National Academy of Science of the United States of America 1987; 84:2097-100.

[19] Stachel SE, Messens E, Montague MV, Zambryski P. Identification of the signal molecules produced by wounded plant cells that activate T-DNA transfer in Agrobacterium tumefaciens. Nature 1985; 318:624-9.

[20] Sheikholeslam SN, Weeks DP. Acetosyringone promotes high frequency transformation of Arabidopsis thaliana explants by Agrobacterium tumefaciens. Plant Molecular Biology 1987; 8:291-8.

[21] He YK, Xue WX, Sun YD, Yu XH, Liu PL, Leafy head formation of the progenies of trangenic plants of Chinese cabbage with exogenous auxin genes. Cell Research 2000; 10:151-6. 